\title{
An AAS Dependent Method for Quantitative Analysis of Essential Trace Elements from Blood Samples of Pakistani Female Breast Cancer Patients
}

\author{
Ghulam Qadir Chanihoon ${ }^{1 * \#, ~ A h s a n u l l a h ~ U n a r ~}{ }^{2 *}$, Ayaz Ali Memon ${ }^{1}$, Tassadaq Hussain Jafar ${ }^{2}$, \\ Huma I. Shaikh ${ }^{1}$, Ayesha Sani' ${ }^{1}$, Raj Kumar'1, Sanam Erum Soomro', Muqaddas Qureshi ${ }^{3}$
}

${ }^{1}$ National Center of Excellence in Analytical Chemistry, University of Sindh, Jamshoro, Pakistan

${ }^{2}$ School of Life Sciences, University of Science and Technology of China, Hefei, China

${ }^{3}$ Government Postgraduate College, Mandian, Abbottabad, Pakistan

Email: *aunar@mail.ustc.edu.cn, *qadir.soomar@scholars.usindh.edu.pk

\begin{abstract}
How to cite this paper: Chanihoon, G.Q., Unar, A., Memon, A.A., Jafar, T.H., Shaikh, H.I., Sani, A., Kumar, R., Soomro, S.E. and Qureshi, M. (2021) An AAS Dependent Method for Quantitative Analysis of Essential Trace Elements from Blood Samples of Pakistani Female Breast Cancer Patients. Advances in Breast Cancer Research, 10, 44-59.
\end{abstract}

https://doi.org/10.4236/abcr.2021.103004

Received: April 16, 2021

Accepted: June 25, 2021

Published: June 28, 2021

Copyright $\odot 2021$ by author(s) and Scientific Research Publishing Inc. This work is licensed under the Creative Commons Attribution International License (CC BY 4.0).

http://creativecommons.org/licenses/by/4.0/

\begin{abstract}
Breast cancer is the second leading cancer in the world. The long-term exposure of some metallic compounds induces different forms of cancer, including breast cancer. Trace elements are essential metals for the physiological functions of the cell on a molecular level and also contribute in treatment of many diseases. The aim of study was to compare the level of essential trace elements, sodium, potassium, calcium, iron, and zinc in breast cancer patients with normal healthy adult women. Total forty-five patients (age range from 25 73 years) were included in this study and divided into three groups according to three different stages of breast cancer including tumor-II, tumor-III and tumor-IV. Blood was collected from all participants after taking history, clinical data and taking consent. However, about fifteen non-cancer healthy women in age range from 26 - 69 years were subjected to this study. The elemental concentrations were determined through atomic absorption spectrophotometer subsequent to microwave-induced acid digestion. The results of $\mathrm{Na}, \mathrm{K}, \mathrm{Zn}$, $\mathrm{Fe}, \mathrm{Ca}$, were observed to decrease in blood samples of breast cancer patients as compared to non-cancer subjects. The results are reliable with other numerous literature reported studies, the efficiency, and deficiency of these trace metals may contribute an important role in the progress of breast cancer.
\end{abstract}

\section{Keywords}

Breast Cancer Blood Samples, Invasive Ductal Carcinoma, Tumor Stages, Essential Elements, FAAS 


\section{Introduction}

Breast cancer is the second leading cause of female cancer mortality [1]. According to the World Health Organization, breast cancer accounts for $16 \%$ of cancer deaths globally. The incidence of breast cancer increases with age, a certain lifestyle, genetics, and environmental factors are important risk factors in breast cancer [2]. The early detection of breast cancer is helpful in early diagnosis. There are many trace elements that are part of metalloenzyme and play a vital role in biological functions, for example structure, the composition of macromolecules, oxygen transport hormonal activities and free radical scavenging [3]. For the normal function of all living cells, potassium ion plays an important role in the normal nerve transmits, it is necessary to have $\mathrm{K}^{+}$transfer via nerve cell membrane. The increased concentration of potassium ion or deficiencies can cause adverse effects in biological functions, such as heart function and electrocardiographic change, etc. [4]. The different types of proteins and enzymes that contain potassium ion and decrease concentration of potassium ion can cause death such as gastrointestinal loss which includes (diarrhea and vomiting) and dieresis which is due to renal loss [5]. The decrease in potassium ion concentration symptom can be as decreased reflex response, paralytic illness, muscle weakness and respiratory paralysis which are rare and occur only in severe conditions. Alkalosis and cardiac arrhythmia are also symptoms of decreased $\left(\mathrm{K}^{+}\right)$ concentration. On the cellular level, the sodium ion channel activity is involved i.e. secretion proliferation and invasion even though lower levels of sodium involve in cancer progression [6] [7] [8] [9]. Hyponatremia or low concentration of sodium in our body is life threatening condition. Calcium is necessary for the regulation of metabolic energy [10] [11]. Calcium intake decreases the hyperproliferation of females mammary glands which are induced by increased fat diets, calcium can also decrease carcinogenic mammary glands and that is induced through 7,12-dimethylbenz[a] anthrancene [12]. But in some other studies, it has been showed that there is a negative relationship between breast cancer risk and the dietary calcium intake [13]. Calcium is also an important role in the proliferation of the cell. This was seen in prone transgenic mice that have obesity which shows that low level of calcium diet impeded loss in body fat in other hand high calcium diets decreased fat accretion and gain in weight on diet causing obesity and considerably enhanced weight and loss in fat during a caloric restriction regiment. Calcium used in diet caused considerably greater anti-obesity effect than supplemental calcium in these observations. A very important rich source of bioactive compounds is milk that can act as synergistically with suppressed activity of 1,25 -di hydroxyl vitamin $\mathrm{D}_{3}$ to favorable effect nutrients portioning loss in fat and efficient metabolism [14].

Different metal proteins are made up of iron $(\mathrm{Fe})$ and it has a very important role in different biochemical functions which can be oxygen transport, sensing electron transfer and catalysis. Myoglobin and hemoglobin are the main sources of hem iron in human foods that are obtaining from fish, poultry conserving 
meat. On the other hand, vegetables and fruits are the sources of non-hem iron supplements and dairy products are very important enzymes activities producing intracellular in bile and hepatic enzymes are involved. Patients of cancer are having low level of iron in their blood [15]. Deficiency of zinc ( $\mathrm{Zn})$ or change in its metabolism can cause acute or chronic inflammatory intestinal disease that can be due low intake or absorption, high excretions are requirements of metabolism and changed immune system [16]. $\mathrm{Zn}$ is primarily available as complex nucleic acids and proteins. It also participates in transmission intermediary metabolism and regulation of genetic information. Further in synthesis, storages, maintenance of chromatin in bio membrane [17]. That's why $\mathrm{Zn}$ is considered to act as protector of cellular growth as well as development of neoplastic cells. Recently during animal experiments protective effect of $\mathrm{Zn}$ has been demonstrated in which different transplantable tumors were inhibited when they have been implanted into animals maintaining on a diet having decreased $\mathrm{Zn}$ [18]. Superoxide dismutase (SOD) is very important enzyme that removes free radicals. $\mathrm{Zn}$ is very essential compound of this enzyme and protects against carcinogenesis and it is very necessary for activation of DNA repair enzymes [19]. It has been examined that low plasma $\mathrm{Zn}$ concentration was seen after trauma stress and in different malignancies patients. Change in $\mathrm{Zn}$ levels has been seen found in lymphatic proliferation along with gastrointestinal tract (GIT) and breast patients [20] [21]. Development or inhibition of cancer due to activity of trace elements is yet unclear although hundreds of investigation that have been performed in this regards [22]. Metal induced oxidative and carcinogenicity has been found in majority of these investigators [23] [24]. Many studies show considerable differences in the concentrations of different trace elements in tissues and blood of healthy persons were compared with cancerous patients [25] [26] [27].

The aim of this study is to understand the level of essential metal ( $\mathrm{Zn}, \mathrm{Fe}, \mathrm{Ca}$, $\mathrm{Na}$, and $\mathrm{K}$ ) from three different stages of breast cancer (T-II, T-III and T-IV) patients and control healthy females. The level of the correlation between breast cancer patients and control for the selected elements and the degree of impact on each other was compared. Therefore, examination of these elements may suggest any presumptive benefits in the analysis of breast cancer.

\section{Material and Methods}

\subsection{Reagents and Glassware}

The ultrapure water obtained from the ELGA lab water system (Bucks, UK) was used throughout the work. Concentrated nitric acid 65\% and hydrogen peroxide $30 \%$ were purchased from Merck (Darmstadt, Germany) and were checked for possible trace metal contamination. Standard solutions of $\mathrm{Na}, \mathrm{K}, \mathrm{Ca}, \mathrm{Fe}$, and $\mathrm{Zn}$ were prepared by dilution of certified standard solutions (1000 ppm) Fluka Kamica (Bush, Switzerland). Dilute working standard solutions were prepared immediately prior to their use by stepwise dilution of the stock standard solution 
with $0.2 \mathrm{M} \mathrm{HNO}_{3}$. All solutions were stored in polyethylene bottles at $4^{\circ} \mathrm{C}$. All glassware and plastic material used were previously soaked for $24 \mathrm{~h}$ in $2 \mathrm{M}$ nitric acid, washed with distilled water, and finally rinsed with de-ionized water and dried and stored in class 100 laminar flow hood.

\subsection{Apparatus}

A Perkin-Elmer model A. Analyst 700 (Norwalk, CT, USA) atomic absorption spectrometer equipped with deuterium background correction was used. The hollow cathode lamps of $\mathrm{Na}, \mathrm{K}, \mathrm{Ca}, \mathrm{Fe}$, and $\mathrm{Zn}$ were run under the conditions at optimum values shown in Table 1 . Integrated absorbance signals computed by the AA spectrometer were employed throughout. A Pel (PMO23) domestic microwave oven (maximum heating power of $900 \mathrm{~W}$ ) was used for digestion of the biological samples. Acid washed polytetrafluoroethylene (PTFE) vessels and flasks were used for preparing and storing solutions.

\subsection{Sample Collection and Pretreatment}

At the beginning of work, about fifteen blood samples of non-cancer healthy women have been collected in the age range from 26 - 69 years shown in Table 2. Besides this, forty-five blood samples were also collected from affected patients of breast cancer as per stages of breast cancer such as tumor-II tumor-III

Table 1. Operational conditions of flame atomic absorption spectrometry for the measurements of different metals.

\begin{tabular}{ccccccc}
\hline Elements & $\begin{array}{c}\text { Wavelength } \\
(\mathrm{nm})\end{array}$ & $\begin{array}{c}\text { Slit width } \\
(\mathrm{nm})\end{array}$ & $\begin{array}{c}\text { Lamp } \\
\text { current }(\mathrm{mA})\end{array}$ & $\begin{array}{c}\text { Burner } \\
\text { height } \\
(\mathrm{mm})\end{array}$ & $\begin{array}{c}\text { Oxidant } \\
\text { (air) L/min }\end{array}$ & $\begin{array}{c}\text { Fuel } \\
\text { (acetylene) } \\
\text { L/min }\end{array}$ \\
\hline $\mathrm{Na}$ & 589 & 0.2 & 10.0 & 7.5 & 17.0 & 2.0 \\
$\mathrm{~K}$ & 766.5 & 0.7 & 10 & 7.5 & 17.0 & 2.0 \\
$\mathrm{Ca}$ & 422.7 & 0.7 & 7.5 & 12.5 & 17.0 & 2.0 \\
$\mathrm{Fe}$ & 248.5 & 0.2 & 7.5 & 7.5 & 17.0 & 2.0 \\
$\mathrm{Zn}$ & 214 & 0.7 & 7.5 & 7.5 & 17.0 & 2.0 \\
\hline
\end{tabular}

Table 2. Resulted data of breast cancer samples classification on the bases of tumor stages and age group.

\begin{tabular}{|c|c|c|c|}
\hline & \multirow{2}{*}{$\begin{array}{l}\text { CONTROL } \\
(\mathrm{n}=15)\end{array}$} & \multirow{2}{*}{$\begin{array}{l}\text { BREAST CANCER } \\
\quad(\mathrm{n}=45)\end{array}$} & STAGES \\
\hline & & & ${ }^{*} \mathrm{~T}-\mathrm{II}(\mathrm{n}=15)$ T-III $(\mathrm{n}=15)$ T-IV $(\mathrm{n}=15)$ \\
\hline \multirow[t]{4}{*}{ Age group } & $26-69$ & $25-73$ & \\
\hline & & Labors 20 & \\
\hline & & Housewife's 18 & \\
\hline & & Professional 22 & \\
\hline \multicolumn{2}{|c|}{ Total number of samples } & 60 & \\
\hline
\end{tabular}


and tumor-IV with the group of fifteen blood samples from each stage to the ratio of age range between $25-73$ years has been studied. The research work is accomplished through the effective and efficient co-ordination of participants because they are multi-approached masses and they are counsel and motivated to well co-operation made possible through providing them all details and benefits of studies. This is for their benefits and for society. Participants have multiple questions regarding research, but they were agreed through information mention in questionnaire including age, dietetic routine, physical information, racial origin, smoking along with health conditions. All affected and non-affected have been interviewed face-to-face by authors with the help of staff nurse of concerned hospitals. The situation of patients was actually worse more than $70 \%$ in terms of constant illness, deficiencies of nutrition, lack of knowledge about diseases, poor conditions and awareness regarding initial treatments of disease. However physical studies such as blood pressure, weight along with height and biochemical information were also taken from patients admitted in Nuclear Institute of Medicine \& Radiotherapy (NIMRA) Jamshoro located in region of Hyderabad Sindh Pakistan. Prior to the sample collection, the protocol of the study was approved by the human ethical committee of the respective hospital and ethical committee of Sindh University, working under the auspices of the Higher Education Commission of Pakistan. The selection of patients with the help of biopsy proved evidence from breast cancer patients through cut-off affected parts (such as left or right breast cancer) prior to some treatment i.e. radiotherapy, chemotherapy and for last three months they were not taking any supplement minerals. While selection of fifteen non-affected females was fit in approximate same socioeconomic impact, age groups and they were healthy family members and do not use any supplements minerals. However, these were not suffering from any type of cancerous disease and also undergone standard medicinal scheduled examination [28]. The histological factors do not converse in this study.

\subsection{Microwave-Assisted Acid Digestion Method}

A microwave-assisted digestion (MDM) procedure was used to attain a minimum time for digestion as compared to convection heating on hot plate. The triplicate samples of breast cancer $(200 \mathrm{mg})$ patients and non-affected females have been placed into Teflon PFA flasks. However, two milliliters of newly prepared mixture of concentrated $\mathrm{HNO}_{3}-\mathrm{H}_{2} \mathrm{O}_{2}(2: 1, \mathrm{v} / \mathrm{v})$ was added to each flask and left for $10 \mathrm{~min}$. Then the flasks were placed in a covered PTFE container. This was then heated following a one-stage digestion program at $80 \%$ of total power ( $900 \mathrm{~W}$ ) 4 - 5 min was required for the decomposition of organic matrix of breast cancer samples. After digestion the flasks were left to cool and the resulting solution was heated to evaporate and remove excess acid then filtered and diluted up $10.0 \mathrm{~mL}$ in volumetric flasks with $0.1 \mathrm{M}$ nitric acid. Blank extraction (without samples) was carried out, performing the well-established labora- 
tory protocols. All digests obtained from both methods were analyzed for $\mathrm{Na}, \mathrm{K}$, $\mathrm{Ca}, \mathrm{Fe}$ and $\mathrm{Zn}$ by AAS. The concentrations were obtained directly from calibration graph after correction of the absorbance for the signal of appropriate reagent blank. The validity and efficiency of the (MDM) were checked with those obtained from a conventional wet digestion method [29].

\section{Result and Discussion}

\subsection{Micronutrients in Control Females}

For the determination of five micronutrients such as $\mathrm{Na}, \mathrm{K}, \mathrm{Ca}, \mathrm{Fe}$ and $\mathrm{Zn}$ from control females, fifteen different blood samples were collected in the age range of 26 - 69 years and analyzed by using atomic absorbance spectroscopy. After analyzing it was calculated that the level of sodium was observed slightly high in the age of 69 years as $3353 \mathrm{mg} / \mathrm{L}$ while low was observed at the age of 29 years as $3174 \mathrm{mg} / \mathrm{L}$. Similarly, potassium level in control females was analyzed as high in the age of 69 years $209.31 \mathrm{mg} / \mathrm{L}$ while low in the age of 26 years as $196 \mathrm{mg} / \mathrm{L}$ shown in Table 3. However, level of calcium was calculated within required range as $87.4 \mathrm{mg} / \mathrm{L}$ in the age 26 years and $80 \mathrm{mg} / \mathrm{L}$ was observed at the age of 69 years. The iron level was obtained $0.59 \mathrm{mg} / \mathrm{L}$ at 26 years while 0.82 was analyzed at the age of 35 years. The essential metal zinc was analyzed in lower required range of control as $0.52 \mathrm{mg} / \mathrm{L}$ at 26 years however $1.52 \mathrm{mg} / \mathrm{L}$ was observed at 60 years. The level of these micronutrients was calculated in required range at same socioeconomic impact, age along life style.

Table 3. Concentrations of essential elements in controls females.

\begin{tabular}{|c|c|c|c|c|c|c|}
\hline S. No & $\begin{array}{c}\text { Age } \\
\text { (year) }\end{array}$ & $\begin{array}{c}\mathrm{Na}(\mathrm{mg} / \mathrm{L}) \\
( \pm \mathrm{SD})\end{array}$ & $\begin{array}{c}\mathrm{K}(\mathrm{mg} / \mathrm{L}) \\
( \pm \mathrm{SD})\end{array}$ & $\begin{array}{c}\mathrm{Ca}(\mathrm{mg} / \mathrm{L}) \\
( \pm \mathrm{SD})\end{array}$ & $\begin{array}{c}\mathrm{Fe}(\mathrm{mg} / \mathrm{L}) \\
( \pm \mathrm{SD})\end{array}$ & $\begin{array}{c}\mathrm{Zn}(\mathrm{mg} / \mathrm{L}) \\
( \pm \mathrm{SD})\end{array}$ \\
\hline 1 & 26 & $3349 \pm 5.04$ & $196.3 \pm 0.12$ & $87.6 \pm 0.31$ & $0.59 \pm 0.01$ & $0.52 \pm 0.02$ \\
\hline 2 & 29 & $3174 \pm 6.09$ & $205.3 \pm 0.19$ & $84.0 \pm 0.47$ & $0.62 \pm 0.02$ & $0.96 \pm 0.04$ \\
\hline 3 & 30 & $3203 \pm 507$ & $203.6 \pm 0.19$ & $81.8 \pm 0.50$ & $0.68 \pm 0.01$ & $0.89 \pm 0.02$ \\
\hline 4 & 32 & $3393 \pm 6.04$ & $201.3 \pm 0.19$ & $80.1 \pm 0.05$ & $0.69 \pm 0.01$ & $1.22 \pm 0.02$ \\
\hline 5 & 35 & $3321 \pm 8.08$ & $198.5 \pm 0.30$ & $86.7 \pm 0.76$ & $0.82 \pm 0.01$ & $0.85 \pm 0.01$ \\
\hline 6 & 36 & $3107 \pm 6.07$ & $198.3 \pm 0.12$ & $89.1 \pm 0.64$ & $0.67 \pm 0.01$ & $0.98 \pm 0.01$ \\
\hline 7 & 39 & $3284 \pm 4.09$ & $204.8 \pm 0.47$ & $81.4 \pm 0.70$ & $0.82 \pm 0.01$ & $0.79 \pm 0.01$ \\
\hline 8 & 41 & $3437 \pm 8.01$ & $201.4 \pm 0.37$ & $83.5 \pm 0.69$ & $0.69 \pm 0.01$ & $0.81 \pm 0.01$ \\
\hline 9 & 44 & $3201 \pm 5.01$ & $206.4 \pm 0.25$ & $87.9 \pm 0.80$ & $0.67 \pm 0.01$ & $0.75 \pm 0.02$ \\
\hline 10 & 46 & $3240 \pm 6.01$ & $207.4 \pm 0.26$ & $88.5 \pm 0.65$ & $0.78 \pm 0.02$ & $0.58 \pm 0.02$ \\
\hline 11 & 55 & $3197 \pm 4.03$ & $202.3 \pm 0.18$ & $89.5 \pm 0.71$ & $0.82 \pm 0.02$ & $0.91 \pm 0.01$ \\
\hline 12 & 58 & $3155 \pm 5.05$ & $205.2 \pm 0.25$ & $89.1 \pm 0.66$ & $0.58 \pm 0.02$ & $1.21 \pm 0.04$ \\
\hline 13 & 60 & $3299 \pm 7.06$ & $200.3 \pm 0.32$ & $83.5 \pm 0.69$ & $0.59 \pm 0.02$ & $1.52 \pm 0.06$ \\
\hline 14 & 64 & $3312 \pm 8.06$ & $202.7 \pm 0.58$ & $79.7 \pm 0.72$ & $0.63 \pm 0.01$ & $1.05 \pm 0.01$ \\
\hline 15 & 69 & $3353 \pm 4.03$ & $209.5 \pm 0.26$ & $80.2 \pm 0.71$ & $0.63 \pm 0.01$ & $0.80 \pm 0.01$ \\
\hline
\end{tabular}




\subsection{Micronutrients Level in Breast Cancer Patients}

The forty-five different blood samples were collected from three stages of breast cancer tumor-II, tumor-III- and tumor-IV in the age range of 25 - 73 years. It was calculated that micronutrients level micronutrients such as sodium, potassium, calcium; iron and zinc were decreased as increase stage of breast cancer from T-II to T-IV [1] [3] [12].

\subsection{Micronutrients Level in $2^{\text {nd }}$ Stage}

\subsubsection{Sodium and Potassium}

The level of sodium in the second stage of breast cancer patients was observed high as $3085 \mathrm{mg} / \mathrm{L}$ at the age of 26 years shown in Table 4 while low value 2945 $\mathrm{mg} / \mathrm{L}$ at the age of 52 years. Potassium level in $2^{\text {nd }}$ stage of breast cancer was analyzed high in the range of $158.1 \mathrm{mg} / \mathrm{L}$ at the age of 44 years shown in Table 5 while low value was calculated $133.2 \mathrm{mg} / \mathrm{L}$ at the age of 61 years, However, calculated results of potassium along with sodium were lower than control females at same socioeconomics impact and age range.

\subsubsection{Calcium, Iron and Zinc}

Calcium is inversely proportional to the stages of breast cancer. Calcium was analyzed in $2^{\text {nd }}$ stage of breast cancer high in the range of $78.83 \mathrm{mg} / \mathrm{L}$ at the age of 36 years, shown in Table 6 however low value of calcium was calculated 65.27 $\mathrm{mg} / \mathrm{L}$ at the age of 61 years. The level of Iron in $2^{\text {nd }}$ stage of breast cancer were found lower than control females, after analyzing it was observed that high

Table 4. Shows the level of sodium in breast cancer patients.

\begin{tabular}{cccccccc}
\hline S. No & $\begin{array}{c}\text { Age } \\
\text { (year) }\end{array}$ & $\begin{array}{c}\text { Na, T-II } \\
(\mathrm{mg} / \mathrm{L})( \pm \mathrm{SD})\end{array}$ & $\begin{array}{c}\text { Age } \\
(\text { year })\end{array}$ & $\begin{array}{c}\mathrm{Na}, \mathrm{T}-\mathrm{III} \\
(\mathrm{mg} / \mathrm{L})( \pm \mathrm{SD})\end{array}$ & $\begin{array}{c}\text { Age } \\
(\text { year })\end{array}$ & $\begin{array}{c}\mathrm{Na}, \mathrm{T}-\mathrm{IV} \\
(\mathrm{mg} / \mathrm{L})( \pm \mathrm{SD})\end{array}$ & $\begin{array}{c}\text { Required } \\
\text { range }\end{array}$ \\
\hline 1 & 29 & $3085 \pm 3.01$ & 25 & $2812 \pm 5.02$ & 28 & $2600 \pm 8.32$ & \\
2 & 36 & $3066 \pm 5.03$ & 29 & $2934 \pm 5.01$ & 37 & $2744 \pm 8.62$ & \\
3 & 34 & $3012 \pm 8.01$ & 31 & $2865 \pm 8.02$ & 41 & $2754 \pm 7.01$ & \\
4 & 36 & $3080 \pm 7.01$ & 34 & $2894 \pm 6.12$ & 44 & $2786 \pm 6.02$ & \\
5 & 36 & $3088 \pm 9.01$ & 35 & $2844 \pm 9.02$ & 45 & $2680 \pm 7.02$ & \\
6 & 38 & $3020 \pm 6.01$ & 38 & $2890 \pm 7.05$ & 48 & $2654 \pm 10.5$ & \\
7 & 39 & $3055 \pm 10.0$ & 40 & $2864 \pm 5.02$ & 51 & $2631 \pm 9.02$ & $3105-3335 \mathrm{mg} / \mathrm{L}$ \\
8 & 39 & $2997 \pm 9.03$ & 41 & $2901 \pm 5.01$ & 53 & $2622 \pm 8.02$ & \\
9 & 41 & $2981 \pm 9.02$ & 44 & $2908 \pm 6.01$ & 54 & $2650 \pm 9.02$ & \\
10 & 41 & $2973 \pm 5.01$ & 45 & $2878 \pm 5.02$ & 60 & $2730 \pm 10.2$ & \\
11 & 44 & $3050 \pm 8.01$ & 48 & $2893 \pm 8.01$ & 64 & $2564 \pm 9.02$ & \\
12 & 47 & $3056 \pm 10.0$ & 53 & $2866 \pm 6.02$ & 65 & $2694 \pm 8.01$ & \\
13 & 52 & $2945 \pm 6.01$ & 56 & $2892 \pm 5.01$ & 69 & $2751 \pm 9.01$ & \\
14 & 56 & $2985 \pm 10.0$ & 56 & $2861 \pm 5.02$ & 70 & $2511 \pm 8.03$ & \\
15 & 61 & $3012 \pm 9.03$ & 65 & $2796 \pm 5.05$ & 73 & $2686 \pm 8.02$ & \\
\hline
\end{tabular}


Table 5. Shows the level of potassium in breast cancer patients.

\begin{tabular}{|c|c|c|c|c|c|c|c|}
\hline S. No & $\begin{array}{c}\text { Age } \\
\text { (year) }\end{array}$ & $\begin{array}{c}\mathrm{T}-\mathrm{II} \\
\mathrm{mg} / \mathrm{L}( \pm \mathrm{SD})\end{array}$ & $\begin{array}{c}\text { Age } \\
\text { (year) }\end{array}$ & $\begin{array}{c}\text { T-III } \\
\mathrm{mg} / \mathrm{L}( \pm \mathrm{SD})\end{array}$ & $\begin{array}{c}\text { Age } \\
\text { (year) }\end{array}$ & $\begin{array}{c}\text { T-IV } \\
\mathrm{mg} / \mathrm{L}( \pm \mathrm{SD})\end{array}$ & $\begin{array}{c}\text { Required } \\
\text { Range }\end{array}$ \\
\hline 1 & 29 & $139.1 \pm 0.073$ & 25 & $139.7 \pm 0.19$ & 28 & $132.6 \pm 0.15$ & \multirow{15}{*}{$\begin{array}{c}136-195 \\
\mathrm{mg} / \mathrm{L}\end{array}$} \\
\hline 2 & 36 & $138.8 \pm 0.072$ & 29 & $138.4 \pm 0.14$ & 37 & $133.5 \pm 0.15$ & \\
\hline 3 & 34 & $136.5 \pm 0.073$ & 31 & $132.5 \pm 0.07$ & 41 & $130.8 \pm 0.13$ & \\
\hline 4 & 36 & $139.4 \pm 0.074$ & 34 & $133.3 \pm 0.20$ & 44 & $134.1 \pm 0.07$ & \\
\hline 5 & 36 & $139.2 \pm 0.073$ & 35 & $131.2 \pm 0.19$ & 45 & $129.3 \pm 0.15$ & \\
\hline 6 & 38 & $145.4 \pm 0.072$ & 38 & $128.3 \pm 0.15$ & 48 & $133.7 \pm 0.15$ & \\
\hline 7 & 39 & $140.3 \pm 0.059$ & 40 & $127.8 \pm 0.14$ & 51 & $125.3 \pm 0.15$ & \\
\hline 8 & 39 & $138.1 \pm 0.072$ & 41 & $134.4 \pm 0.16$ & 53 & $131.0 \pm 0.13$ & \\
\hline 9 & 41 & $134.7 \pm 0.078$ & 44 & $129.0 \pm 0.16$ & 54 & $125.8 \pm 0.12$ & \\
\hline 10 & 41 & $147.7 \pm 0.075$ & 45 & $130.2 \pm 0.17$ & 60 & $134.5 \pm 0.13$ & \\
\hline 11 & 44 & $158.5 \pm 0.077$ & 48 & $131.8 \pm 0.17$ & 64 & $127.8 \pm 0.22$ & \\
\hline 12 & 47 & $139.5 \pm 0.085$ & 53 & $133.3 \pm 0.16$ & 65 & $128.2 \pm 0.07$ & \\
\hline 13 & 52 & $137.9 \pm 0.058$ & 56 & $133.5 \pm 0.75$ & 69 & $132.5 \pm 0.15$ & \\
\hline 14 & 56 & $134.4 \pm 0.059$ & 56 & $135.9 \pm 0.14$ & 70 & $126.7 \pm 0.13$ & \\
\hline 15 & 61 & $133.2 \pm 0.074$ & 65 & $134.3 \pm 0.18$ & 73 & $125.3 \pm 0.15$ & \\
\hline
\end{tabular}

Table 6. Shows the level of calcium in breast cancer patients.

\begin{tabular}{|c|c|c|c|c|c|c|c|}
\hline $\begin{array}{l}\text { S. } \\
\text { No }\end{array}$ & $\begin{array}{c}\text { Age } \\
\text { (year) }\end{array}$ & $\begin{array}{l}\text { T-II mg/L } \\
( \pm S D)\end{array}$ & $\begin{array}{c}\text { Age } \\
\text { (year) }\end{array}$ & $\begin{array}{c}\mathrm{Ca}, \mathrm{T}-\mathrm{III} \\
\mathrm{mg} / \mathrm{L}( \pm \mathrm{SD})\end{array}$ & $\begin{array}{l}\text { Age } \\
\text { (year) }\end{array}$ & $\begin{array}{c}\mathrm{Ca}, \mathrm{T}-\mathrm{IV} \\
\mathrm{mg} / \mathrm{L}( \pm \mathrm{SD})\end{array}$ & $\begin{array}{c}\text { Required } \\
(\mathrm{mg} / \mathrm{L})\end{array}$ \\
\hline 1 & 29 & $71.23 \pm 1.32$ & 25 & $63.23 \pm 1.18$ & 28 & $58.01 \pm 1.09$ & \\
\hline 2 & 36 & $75.23 \pm 1.52$ & 29 & $68.43 \pm 2.08$ & 37 & $55.76 \pm 2.10$ & \\
\hline 3 & 34 & $75.40 \pm 2.35$ & 31 & $62.16 \pm 2.09$ & 41 & $58.13 \pm 1.09$ & \\
\hline 4 & 36 & $78.83 \pm 2.07$ & 34 & $72.46 \pm 2.07$ & 44 & $59.66 \pm 1.25$ & \\
\hline 5 & 36 & $68.50 \pm 3.15$ & 35 & $69.13 \pm 2.08$ & 45 & $58.53 \pm 2.09$ & \\
\hline 6 & 38 & $77.63 \pm 1.20$ & 38 & $67.13 \pm 1.08$ & 48 & $52.12 \pm 1.20$ & \\
\hline 7 & 39 & $75.17 \pm 2.08$ & 40 & $65.43 \pm 2.08$ & 51 & $52.53 \pm 1.10$ & \\
\hline 8 & 39 & $70.07 \pm 3.08$ & 41 & $68.31 \pm 2.29$ & 53 & $53.03 \pm 3.10$ & $85-102$ \\
\hline 9 & 41 & $67.20 \pm 1.17$ & 44 & $63.81 \pm 2.09$ & 54 & $58.81 \pm 2.48$ & \\
\hline 10 & 41 & $74.37 \pm 2.08$ & 45 & $61.01 \pm 3.16$ & 60 & $58.91 \pm 1.16$ & \\
\hline 11 & 44 & $76.37 \pm 2.27$ & 48 & $62.21 \pm 2.24$ & 64 & $57.13 \pm 1.10$ & \\
\hline 12 & 47 & $75.01 \pm 1.13$ & 53 & $65.41 \pm 1.15$ & 65 & $59.22 \pm 1.10$ & \\
\hline 13 & 52 & $66.17 \pm 2.09$ & 56 & $68.72 \pm 2.14$ & 69 & $49.76 \pm 2.11$ & \\
\hline 14 & 56 & $75.13 \pm 3.08$ & 56 & $68.62 \pm 1.08$ & 70 & $50.06 \pm 1.11$ & \\
\hline 15 & 61 & $65.27 \pm 2.08$ & 65 & $60.10 \pm 2.16$ & 73 & $49.43 \pm 2.11$ & \\
\hline
\end{tabular}

amount of iron observed at the of $0.57 \mathrm{mg} / \mathrm{L}$ at 29 years shown in Table 7 while low value was observed at the age of 36 years in the range of $47.0 \mathrm{mg} / \mathrm{L}$. Zinc was also calculated lower level in $2^{\text {nd }}$ stage of breast cancer patients as compared with 
control females. However, zinc obtained a high level of $0.75 \mathrm{mg} / \mathrm{L}$ at the age of 26 years shown in Table 8. While low level of $\mathrm{Zn} 0.51 \mathrm{mg} / \mathrm{L}$ was observed at the age of 61 years.

Table 7. Shows the level of iron in breast cancer patients.

\begin{tabular}{|c|c|c|c|c|c|c|c|}
\hline $\begin{array}{l}\text { S. } \\
\text { No }\end{array}$ & $\begin{array}{c}\text { Age } \\
\text { (year) }\end{array}$ & 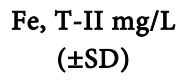 & $\begin{array}{c}\text { Age } \\
\text { (year) }\end{array}$ & $\begin{array}{c}\text { Fe, T-III mg/L } \\
( \pm S D)\end{array}$ & $\begin{array}{c}\text { Age } \\
\text { (year) }\end{array}$ & $\begin{array}{c}\mathrm{Fe}, \mathrm{T}-\mathrm{IV} \\
\mathrm{mg} / \mathrm{L}( \pm \mathrm{SD})\end{array}$ & $\begin{array}{c}\text { Required } \\
(\mathrm{mg} / \mathrm{L})\end{array}$ \\
\hline 1 & 29 & $0.57 \pm 0.011$ & 25 & $0.49 \pm 0.021$ & 28 & $0.41 \pm 0.012$ & \\
\hline 2 & 36 & $0.51 \pm 0.019$ & 29 & $0.47 \pm 0.015$ & 37 & $0.39 \pm 0.024$ & \\
\hline 3 & 34 & $0.52 \pm 0.012$ & 31 & $0.47 \pm 0.026$ & 41 & $0.42 \pm 0.011$ & \\
\hline 4 & 36 & $0.47 \pm 0.010$ & 34 & $0.42 \pm 0.006$ & 44 & $0.38 \pm 0.013$ & \\
\hline 5 & 36 & $0.49 \pm 0,011$ & 35 & $0.51 \pm 0.021$ & 45 & $0.30 \pm 0.012$ & \\
\hline 6 & 38 & $0.59 \pm 0.011$ & 38 & $0.46 \pm 0.021$ & 48 & $0.32 \pm 0.010$ & \\
\hline 7 & 39 & $0.56 \pm 0.018$ & 40 & $0.49 \pm 0.018$ & 51 & $0.39 \pm 0.019$ & \\
\hline 8 & 39 & $0.48 \pm 0.014$ & 41 & $0.41 \pm 0.010$ & 53 & $0.40 \pm 0.017$ & $0.6-1.7$ \\
\hline 9 & 41 & $0.55 \pm 0.026$ & 44 & $0.45 \pm 0.031$ & 54 & $0.32 \pm 0.023$ & \\
\hline 10 & 41 & $0.59 \pm 0.016$ & 45 & $0.48 \pm 0.022$ & 60 & $0.36 \pm 0.018$ & \\
\hline 11 & 44 & $0.51 \pm 0.011$ & 48 & $0.48 \pm 0.021$ & 64 & $0.37 \pm 0.019$ & \\
\hline 12 & 47 & $0.57 \pm 0.022$ & 53 & $0.51 \pm 0.019$ & 65 & $0.33 \pm 0.014$ & \\
\hline 13 & 52 & $0.52 \pm 0.012$ & 56 & $0.42 \pm 0.021$ & 69 & $0.39 \pm 0.012$ & \\
\hline 14 & 56 & $0.58 \pm 0.023$ & 56 & $0.45 \pm 0.023$ & 70 & $0.31 \pm 0.015$ & \\
\hline 15 & 61 & $0.49 \pm 0.010$ & 65 & $0.41 \pm 0.013$ & 73 & $0.34 \pm 0.023$ & \\
\hline
\end{tabular}

Table 8. Shows the level of Zinc in breast cancer patients.

\begin{tabular}{|c|c|c|c|c|c|c|c|}
\hline S. No & $\begin{array}{c}\text { Age } \\
\text { (year) }\end{array}$ & $\begin{array}{c}\mathrm{Zn}, \mathrm{T}-\mathrm{II} \mathrm{mg} / \mathrm{L} \\
( \pm \mathrm{SD})\end{array}$ & $\begin{array}{c}\text { Age } \\
\text { (year) }\end{array}$ & $\begin{array}{c}\mathrm{Zn}, \mathrm{T}-\mathrm{III} \mathrm{mg} / \mathrm{L} \\
( \pm \mathrm{SD})\end{array}$ & $\begin{array}{c}\text { Age } \\
\text { (year) }\end{array}$ & $\begin{array}{c}\mathrm{Zn}, \mathrm{T}-\mathrm{IV} \\
\mathrm{mg} / \mathrm{L}( \pm \mathrm{SD})\end{array}$ & $\begin{array}{l}\text { Required } \\
(\mathrm{mg} / \mathrm{L})\end{array}$ \\
\hline 1 & 29 & $0.75 \pm 0.027$ & 25 & $0.66 \pm 0.027$ & 28 & $0.29 \pm 0.011$ & \\
\hline 2 & 36 & $0.49 \pm 0.020$ & 29 & $0.58 \pm 0.017$ & 37 & $0.26 \pm 0.013$ & \\
\hline 3 & 34 & $0.51 \pm 0.012$ & 31 & $0.50 \pm 0.017$ & 41 & $0.22 \pm 0.010$ & \\
\hline 4 & 36 & $0.50 \pm 0.035$ & 34 & $0.45 \pm 0.014$ & 44 & $0.16 \pm 0.014$ & \\
\hline 5 & 36 & $0.61 \pm 0.028$ & 35 & $0.65 \pm 0.021$ & 45 & $0.19 \pm 0.015$ & \\
\hline 6 & 38 & $0.58 \pm 0.041$ & 38 & $0.57 \pm 0.016$ & 48 & $0.31 \pm 0.006$ & \\
\hline 7 & 39 & $0.68 \pm 0.026$ & 40 & $0.58 \pm 0.013$ & 51 & $0.39 \pm 0.005$ & \\
\hline 8 & 39 & $0.70 \pm 0.017$ & 41 & $0.63 \pm 0.020$ & 53 & $0.35 \pm 0.008$ & $0.5-1.9$ \\
\hline 9 & 41 & $0.59 \pm 0.027$ & 44 & $0.52 \pm 0.039$ & 54 & $0.25 \pm 0.004$ & \\
\hline 10 & 41 & $0.66 \pm 0.031$ & 45 & $0.55 \pm 0.022$ & 60 & $0.38 \pm 0.010$ & \\
\hline 11 & 44 & $0.69 \pm 0.014$ & 48 & $0.60 \pm 0.017$ & 64 & $0.15 \pm 0.021$ & \\
\hline 12 & 47 & $0.49 \pm 0.017$ & 53 & $0.66 \pm 0.019$ & 65 & $0.22 \pm 0.048$ & \\
\hline 13 & 52 & $0.57 \pm 0.019$ & 56 & $0.56 \pm 0.030$ & 69 & $0.28 \pm 0.006$ & \\
\hline 14 & 56 & $0.62 \pm 0.044$ & 56 & $0.59 \pm 0.019$ & 70 & $0.18 \pm 0.003$ & \\
\hline 15 & 61 & $0.51 \pm 0.032$ & 65 & $0.51 \pm 0.024$ & 73 & $0.15 \pm 0.012$ & \\
\hline
\end{tabular}




\subsection{Micronutrients Level in $3^{\text {rd }}$ Stage}

\subsubsection{Sodium and Potassium}

The sodium level in $3^{\text {rd }}$ stage of breast was calculated in lower than $2^{\text {nd }}$ stage as well control females, the level which was observed high $2934 \mathrm{mg} / \mathrm{L}$ in the age range of 29 years while low $2796 \mathrm{mg} / \mathrm{L}$ observed at the age of 65 years. After analyzing it was observed that sodium is inversely proportional to the stages of breast cancer. However, potassium in $3^{\text {rd }}$ stage of breast cancer was also observed lower than $2^{\text {nd }}$ stage of breast along with healthy control females. The level of essential micronutrient potassium calculated in the $3^{\text {rd }}$ stage of breast cancer was high $139.7 \mathrm{mg} / \mathrm{L}$ at the age of 25 years while low $134.3 \mathrm{mg} / \mathrm{L}$ was observed at the age of 65 years. The level of sodium and potassium are inversely proportional to the stages of breast cancer patients.

\subsubsection{Calcium, Iron and Zinc}

Calcium is inversely proportional to the stages of breast cancer, the level of calcium observed in the $3^{\text {rd }}$ stage of breast cancer was found lower than control females. Calcium which was analyzed in the $3^{\text {rd }}$ stage was high $72.4 \mathrm{mg} / \mathrm{L}$ at the age of 34 years while low $60.1 \mathrm{mg} / \mathrm{L}$ observed at the age of 65 years. The level of iron was also decreased as increases the stages of breast cancer, however iron in $3^{\text {rd }}$ stage of breast cancer analyzed high $0.51 \mathrm{mg} / \mathrm{L}$ at the age range of 35 years while low value was also obtained $0.41 \mathrm{mg} / \mathrm{L}$ at the age of 65 years. Zinc was also observed lower than control females; after analyzing it was clearly obtained lower level of $\mathrm{Zn}$ in $3^{\text {rd }}$ stage of breast cancer than $2^{\text {nd }}$ stage of breast cancer. However, the calculated range which was high $0.66 \mathrm{mg} / \mathrm{L}$ at the age of 25 years while low value $0.51 \mathrm{mg} / \mathrm{L}$ was observed at the age of 65 years.

\subsection{Micronutrients Level in $4^{\text {th }}$ Stage}

\subsubsection{Sodium and Potassium}

Level of sodium in $4^{\text {th }}$ stage of breast cancer decreased as compared to control females; however, sodium which was observed in 4th stage of breast cancer was observed $2786 \mathrm{mg} / \mathrm{L}$ at the age range of 44 years while low value was obtained $2511 \mathrm{mg} / \mathrm{L}$ at the age of 70 years. It was observed that the sodium level increased inversely proportional to the stages of breast cancer. The potassium level was also decreasing as it increases stages of breast cancer among women. The level of potassium observed in $4^{\text {th }}$ stage was high $133 \mathrm{mg} / \mathrm{L}$ at the age range of 48 years while low value was calculated $125.3 \mathrm{mg} / \mathrm{L}$ at the age of 73 years.

\subsubsection{Calcium, Iron and Zinc}

The level of calcium decreased by increasing stages of breast cancer patients, however it is inversely proportional to the stages of breast cancer. Calcium level observed in $4^{\text {th }}$ stage of breast cancer high $59.22 \mathrm{mg} / \mathrm{L}$ at the age range of 44 years while low-level value was obtained $49.3 \mathrm{mg} / \mathrm{L}$ at the age of 73 years. The iron level was also decreased by increasing the stages of breast cancer patients, level of iron in $4^{\text {th }}$ stage of breast was calculated high $0.41 \mathrm{mg} / \mathrm{L}$ at the age range of 28 years however low level of iron was calculated $0.30 \mathrm{mg} / \mathrm{L}$ at the age of 48 
years. Zinc observed in $4^{\text {th }}$ stage of breast cancer was high $0.39 \mathrm{mg} / \mathrm{L}$ at the age of 54 years while low level of zinc was also calculated $0.15 \mathrm{mg} / \mathrm{L}$ at the age of 73 years. After analyzing it was calculated that zinc is inversely proportional to the stages of breast cancer [30].

The demographic data of the female breast cancer patients and healthy women (hereafter called "controls") Subjects in the two groups were closely matched with age, residential area, profession, and same dietary habits. However, some patients were smokers. Various types of cancer are found in females such as cervical cancer, skin cancer, ovarian cancer, but breast cancer is the leading cause of death all over the world. Incidence rates of breast cancer have been increased over the previous few decades in western countries, particularly among postmenopausal females. The rate of breast cancer is increased in developing countries especially in Asia where the lack of knowledge of basic health such as deficiency of essential macronutrients living style in neighborhood area. The biochemical parameters of cancerous patients were also altered. According to origin of breast cancer it is divided into four types i.e. tumor-I, tumor-II, tumor-III, and tumor-IV. To determine the micronutrients level in breast cancer patient such as $\mathrm{Na}, \mathrm{K}, \mathrm{Ca}$, $\mathrm{Fe}$, and $\mathrm{Zn}$ in three different stages of breast cancer patients, while the tumor in stage one of breast cancer patient was not found in that area because women's are unaware about it, lack of knowledge about initial arise up of breast cancer [31].

\subsection{Stage-II}

The micronutrient level in stage-II of breast cancer patients was observed low level as compared to control females because in this stage the tumor size II-A $\leq 2$ $\mathrm{cm}$ and has spread to lymph nodes or $2-5 \mathrm{~cm}$ and has spread to lymph nodes. While stage II-B $2-5 \mathrm{~cm}$ and has spread to lymph nodes or $>5 \mathrm{~cm}$ and has not spread to lymph nodes. The level of micronutrients in $2^{\text {nd }}$ stage of breast cancer is inversely proportional to the stages of breast cancer that why the micronutrients decrease as increases stage of cancer.

\subsection{Stage-III}

Five different micronutrients were analyzed and compared with control females. After analyzing it was observed that the levels of micronutrients were calculated, however micronutrients level decreased with increase stage of BC.

\subsection{Stage-IV}

The level of micronutrients observed in the $4^{\text {th }}$ stage of $\mathrm{BC}$ was at a low level as compared to control females, because low intake of vitamin along with essential minerals may cause deficiency of micronutrients in $\mathrm{BC}$ patients. The treatments include radiotherapy means to kill cancer cell through radiation therapy or kill cancerous cell through chemotherapy may cause mostly vomiting along with diarrhea after this very serious condition occur that is why low level of such micronutrients was observed in last stage of breast cancer patients. The level of so- 
dium in three different stages of breast cancer patients was observed lower as compared to control females; however, it is inversely proportional to the stages of BC patients. After analyzing it was obtained that the level of sodium was observed low value in fourth stage of breast cancer than other stages of $\mathrm{BC}$, the level of sodium decrease due to dosage of chemotherapy in BC patients. The low level of sodium and potassium were observed in breast cancer patient than control females. Because repeat cycles of chemotherapy may cause dehydration along with diarrhea vomiting and loss of energy through sweating that's why the level of sodium \& potassium was decreased in BC patients. Potassium observed in three different stages of breast cancer was low from tumor-II to tumor-IV due to increase stages of $\mathrm{BC}$ cause decrease level of potassium.

However, one of the most important macronutrients is calcium because it plays an essential role in metabolism. Mostly the functions are relying on the good case of the extracellular $\mathrm{Ca}$ with respect to narrow range. The interruption of that firmly ordered homeostatic system cause mess of Ca metabolism and that will predictably affect cellular functions. The low intake of $\mathrm{Ca}$ aggregates the risk of $\mathrm{BC}$ especially in women having pre-menopausal issues. Ca has been examined in 3 different stages of breast cancer were low than control females. It was seen after checking that when the stage of breast cancer increases from tumor-II to IV the Ca level decreases. The noticeable disease in hemoglobin, hematocrit, packed cell volume, hemoglobin composed of corpuscular and RBC was examined inpatient having cancer than others. The study of biochemical changes in the period of deadly conversation indicated as a form of chemical biopsy due to their facilitation of the diagnosis of organ abnormalities in the chemical eye. Fatigue among cancer patients caused by anemic condition is associated low hemoglobin. Patients having anemia hemoglobin levels are low and thus patients come often tired and they are having lower energy. This is due to fact that there is not enough hemoglobin to carry oxygen to the stationary tissues. So, there is no enough oxygen which can convert nutrients into energy components. The other blood parameter having anemia include $\mathrm{RBC}, \mathrm{MCH}, \mathrm{MCV}$, and hematocrit could also below. The change in toxic and trace elements in $\mathrm{BC}$ patients has got inverse relationship with biochemical parameters. Trace elements act at subcellular or cellular level via various mechanisms. One of such mechanism can be shown as the interaction between hormones and trace elements that maintain metabolism of higher biochemical substrate, therefore, a possible association between etiology of cancer and trace elements might be expected [32] [33] [34]. It was studied that the status of $\mathrm{Zn}$ was changed in BC samples of confirmed biopsy cases as compared to non-cancerous females having same age group. Current resulted data shows the considerably decreased levels $\mathrm{Ca}, \mathrm{Zn}, \mathrm{Fe}, \mathrm{Na}$, and $\mathrm{K}$ in women having $\mathrm{BC}$ in increasing order as breast $\mathrm{N}$, ovary $\mathrm{N}$ as compared to control females of same age. Our observation consisted of other epidemiological investigations that show decreased levels of different micronutrients in various cancer patients as shown in Figure 1 [35]. It was also been shown that the content 


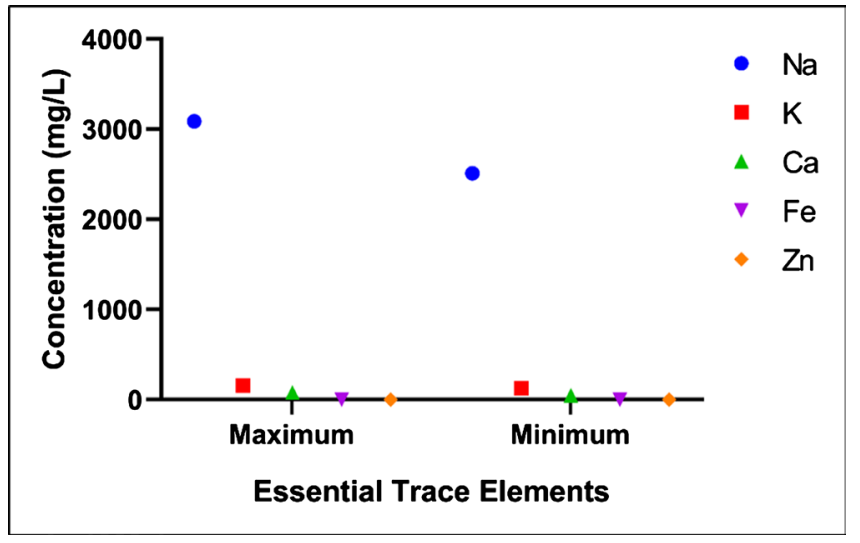

Figure 1. The concentration of essential trace elements.

of $\mathrm{Zn}$ in blood serum of tumors was lower than non-cancerous females. $\mathrm{Zn}$ is very common to induce the production of metallothionein. That is enriched in cytosine and it is an excellent scavenger of radical having hydroxyl group. Therefore now it has been clear that $\mathrm{Zn}$ has got many roles as an antioxidant and is thus an extraordinary candidate for clinical chemoprevention trials in humans [36]. One of major problem in cancer patients is malnutrition but it is not prevented in all cancer cases but is common and serious problems in case of breast and mouth cancer [37]. Commonly it has been seen that cancer patients are having inadequate protein and energy intakes high metabolic rate and several abnormalities in lipid, energy carbohydrate, protein, metabolism. During treatment of cancer through chemotherapy and radiotherapy is also responsible for potential damage to nutrition levels [38]. The risk of certain types of BC, mouth, and oropharyngeal cancer is may be increased due to intake of diet. This is because of lack of essential vitamins and trace elements in poor diet [39].

\section{Conclusion}

The result of this investigation showed that patients having $\mathrm{BC}$ have got a low level of important trace elements such as ( $\mathrm{Na}, \mathrm{K}, \mathrm{Ca}, \mathrm{Fe}$ and $\mathrm{Zn}$ ) when these cancerous patients compared with healthy women. This study also showed that some diet intake and inhibition of toxic elements may increase the risk of cancer and related diseases. Such toxic elements and diet can be smoking, treated unclean water. But this study now provides a significant amount of epidemiologic evidence that role of essential trace elements has got influential effect on cancer risk. Further necessary studies should be carried out to reveal mechanisms of trace elements carcinogenic patients admitted in various hospitals that should be checked for essential elements measurement in their biological sample. So that markers of cancer can be predicated on the earliest possible stage.

\section{Acknowledgements}

Authors are acknowledged to the NIMRA, LUMHS and NCEAC Jamshoro for providing facilities to collect blood samples from breast cancer patients in Pakistan. 


\section{Conflicts of Interest}

The authors declare no conflicts of interest regarding the publication of this paper.

\section{References}

[1] Grandics, P. (2003) Cancer: A Single Disease with a Multitude of Manifestions? Journal of Carcinogenesis, 2, 9. https://doi.org/10.1186/1477-3163-2-9

[2] Silvera, S.A.N. and Rohan, T.E. (2007) Trace Elements and Cancer Risk: A Review of the Epidemiologic Evidence. Cancer Causes \& Control, 18, 7-27. https://doi.org/10.1007/s10552-006-0057-Z

[3] Yaman, M., Kaya, G. and Yekeler, H. (2007) Distribution of Trace Metal Concentrations in Paired Cancerous and Non-Cancerous Human Stomach Tissues. World Journal of Gastroenterology: WJG, 13, 612-618.

[4] Schrauzer, G. (2008) Effects of Selenium and Low Levels of Lead on Mammary Tumor Development and Growth in MMTV-Infected Female Mice. Biological Trace Element Research, 125, Article No. 268. https://doi.org/10.1007/s12011-008-8172-1

[5] Wu, H.-D.I., et al. (2006) Differentiation of Serum Levels of Trace Elements in Normal and Malignant Breast Patients. Biological Trace Element Research, 113, 9-18. https://doi.org/10.1385/BTER:113:1:9

[6] Anton, S.D., et al. (2013) Effect of a Novel Dietary Supplement on pH Levels of Healthy Volunteers: A Pilot Study. Journal of Integrative Medicine, 11, 384-388. https://doi.org/10.3736/jintegrmed2013049

[7] Berghmans, T., Paesmans, M. and Body, J.-J. (2000) A Prospective Study on Hyponatraemia in Medical Cancer Patients: Epidemiology, Aetiology and Differential Diagnosis. Supportive Care in Cancer, 8, 192-197.

https://doi.org/10.1007/s005200050284

[8] Bennett, H., et al. (2004) Cognitive Impairment after Transurethral Resection of the Prostate (TURP). Disability and Rehabilitation, 26, 1381-1387. https://doi.org/10.1080/09638280400000229

[9] Do Freda, B.J. (2004) Evaluation of Hyponatremia: A Little Physiology Goes a Long Way. Cleveland Clinic Journal of Medicine, 71, 639-650.

[10] Sergeev, I. (2004) Calcium as a Mediator of 1,25-Dihydroxyvitamin D3-Induced Apoptosis. The Journal of Steroid Biochemistry and Molecular Biology, 89, 419-425. https://doi.org/10.1016/j.jsbmb.2004.03.010

[11] Xue, L., et al. (1999) Influence of Dietary Calcium and Vitamin D on Diet-Induced Epithelial Cell Hyperproliferation in Mice. Journal of the National Cancer Institute, 91, 176-181. https://doi.org/10.1093/jnci/91.2.176

[12] Kesse-Guyot, E., et al. (2007) Dairy Products, Calcium and the Risk of Breast Cancer: Results of the French SU. VI. MAX Prospective Study. Annals of Nutrition and Metabolism, 51, 139-145. https://doi.org/10.1159/000103274

[13] Abbas, S., Linseisen, J. and Chang-Claude, J. (2007) Dietary Vitamin D and Calcium Intake and Premenopausal Breast Cancer Risk in a German Case-Control Study. Nutrition and Cancer, 59, 54-61. https://doi.org/10.1080/01635580701390223

[14] Shin, M.-H., et al. (2002) Intake of Dairy Products, Calcium, and Vitamin D and Risk of Breast Cancer. Journal of the National Cancer Institute, 94, 1301-1310. https://doi.org/10.1093/jnci/94.17.1301 
[15] Kaaks, R., et al. (2005) Postmenopausal Serum Androgens, Oestrogens and Breast Cancer Risk: The European Prospective Investigation into Cancer and Nutrition. Endocrine-Related Cancer, 12, 1071-1082. https://doi.org/10.1677/erc.1.01038

[16] Tapiero, H. and Tew, K.D. (2003) Trace Elements in Human Physiology and Pathology: Zinc and Metallothioneins. Biomedicine \& Pharmacotherapy, 57, 399-411. https://doi.org/10.1016/S0753-3322(03)00081-7

[17] Sturniolo, G., et al. (2000) The Many Functions of Zinc in Inflammatory Conditions of the Gastrointestinal Tract. The Journal of Trace Elements in Experimental Medicine, 13, 33-39. https://doi.org/10.1002/(SICI)1520-670X(2000)13:1<33::AID-JTRA5>3.0.CO;2-K

[18] Kolachi, N.F., et al. (2012) Investigation of Essential Trace and Toxic Elements in Biological Samples (Blood, Serum and Scalp Hair) of Liver Cirrhotic/Cancer Female Patients before and after Mineral Supplementation. Clinical Nutrition, 31, 967-973. https://doi.org/10.1016/j.clnu.2012.04.015

[19] Platz, E.A., et al. (2002) Prediagnostic Toenail Cadmium and Zinc and Subsequent Prostate Cancer Risk. The Prostate, 52, 288-296. https://doi.org/10.1002/pros.10115

[20] Siddiqui, M., et al. (2006) Comparison of Some Trace Elements Concentration in Blood, Tumor Free Breast and Tumor Tissues of Women with Benign and Malignant Breast Lesions: An Indian Study. Environment International, 32, 630-637. https://doi.org/10.1016/j.envint.2006.02.002

[21] Kuo, H.W., et al. (2002) Serum and Tissue Trace Elements in Patients with Breast Cancer in Taiwan. Biological Trace Element Research, 89, 1-11. https://doi.org/10.1385/BTER:89:1:1

[22] Zanke, B.W., et al. (2007) Genome-Wide Association Scan Identifies a Colorectal Cancer Susceptibility Locus on Chromosome 8q24. Nature Genetics, 39, 989-994. https://doi.org/10.1038/ng2089

[23] Karadag, A., et al. (2004) Bone Sialoprotein, Matrix Metalloproteinase 2, and av $\beta 3$ Integrin in Osteotropic Cancer Cell Invasion. Journal of the National Cancer Institute, 96, 956-965. https://doi.org/10.1093/jnci/djh169

[24] Czerniecki, B.J., et al. (2007) Targeting HER-2/neu in Early Breast Cancer Development Using Dendritic Cells with Staged Interleukin-12 Burst Secretion. Cancer Research, 67, 1842-1852.

[25] Lu, S.-L., et al. (2006) Loss of Transforming Growth Factor- $\beta$ Type II Receptor Promotes Metastatic Head-and-Neck Squamous Cell Carcinoma. Genes \& Development, 20, 1331-1342. https://doi.org/10.1101/gad.1413306

[26] Kibar, Y., et al. (2006) Prognostic Value of Cytology, Nuclear Matrix Protein 22 (NMP22) Test, and Urinary Bladder Cancer II (UBC II) Test in Early Recurrent Transitional Cell Carcinoma of the Bladder. Annals of Clinical \& Laboratory Science, 36, p. 31-38.

[27] Neve, R.M., et al. (2006) A Collection of Breast Cancer Cell Lines for the Study of Functionally Distinct Cancer Subtypes. Cancer Cell, 10, 515-527.

https://doi.org/10.1016/j.ccr.2006.10.008

[28] Zowczak, M., et al. (2001) Analysis of Serum Copper and Zinc Concentrations in Cancer Patients. Biological Trace Element Research, 82, Article No. 1. https://doi.org/10.1385/BTER:82:1-3:001

[29] Afridi, H.I., et al. (2006) Essential Trace and Toxic Element Distribution in the Scalp Hair of Pakistani Myocardial Infarction Patients and Controls. Biological Trace Element Research, 113, 19-34. https://doi.org/10.1385/BTER:113:1:19 
[30] Cui, Y., et al. (2007) Levels of Zinc, Selenium, Calcium, and Iron in Benign Breast Tissue and Risk of Subsequent Breast Cancer. Cancer Epidemiology and Prevention Biomarkers, 16, 1682-1685. https://doi.org/10.1158/1055-9965.EPI-07-0187

[31] Pasha, Q., Malik, S.A. and Shah, M.H. (2008) Statistical Analysis of Trace Metals in the Plasma of Cancer Patients versus Controls. Journal of Hazardous Materials, 153, 1215-1221. https://doi.org/10.1016/j.jhazmat.2007.09.115

[32] Wadhwa, S.K., et al. (2015) Interaction between Carcinogenic and Anti-Carcinogenic Trace Elements in the Scalp Hair Samples of Different Types of Pakistani Female Cancer Patients. Clinica Chimica Acta, 439, 178-184. https://doi.org/10.1016/j.cca.2014.10.007

[33] Rodu, B. and Jansson, C. (2004) Smokeless Tobacco and Oral Cancer: A Review of the Risks and Determinants. Critical Reviews in Oral Biology \& Medicine, 15, 252-263. https://doi.org/10.1177/154411130401500502

[34] Magalova, T., et al. (1999) Copper, Zinc and Superoxide Dismutase in Precancerous, Benign Diseases and Gastric, Colorectal and Breast Cancer. Neoplasma, 46, 100-104.

[35] Kazi, T.G., et al. (2007) Evaluation of Zinc Status in Whole Blood and Scalp Hair of Female Cancer Patients. Clinica Chimica Acta, 379, 66-70. https://doi.org/10.1016/j.cca.2006.12.009

[36] Zhai, H., Chen, X. and Hu, Z. (2003) Study on the Relationship between Intake of Trace Elements and Breast Cancer Mortality with Chemometric Methods. Computational Biology and Chemistry, 27, 581-586. https://doi.org/10.1016/S1476-9271(03)00049-5

[37] Savino, W., et al. (2007) The Thymus Is a Common Target in Malnutrition and Infection. British Journal of Nutrition, 98, S11-S16. https://doi.org/10.1017/S0007114507832880

[38] Oneschuk, D. and Younus, J. (2008) Natural Health Products and Cancer Chemotherapy and Radiation Therapy. Oncology Reviews, 1, 233-242. https://doi.org/10.1007/s12156-008-0028-6

[39] Spitz, M.R., et al. (2004) Subgroup Report: Head and Neck Cancer. IARC Scientific Publications, No. 157, 41-47. 